\title{
Cholinergic signal transduction cascades in rat pinealocytes: functional and ontogenetic aspects
}

\author{
Christof Schomerus, Horst-Werner Korf*
}

\author{
Dr. Senckenbergische Anatomie, Anatomisches Institut II, \\ Johann Wolfgang Goethe-Universität Frankfurt, Theodor-Stern-Kai 7, \\ 60590 Frankfurt/Main, Germany
}

(Received 21 January 1999; accepted 8 March 1999)

\begin{abstract}
In adult rat pinealocytes, acetylcholine activates nicotinic receptors whose stimulation causes a depolarization of the cells, opening of voltage-gated cation channels of the L-type and subsequent increase in the intracellular calcium ion concentration. These events trigger a release of glutamate that, by its action on metabotropic glutamate type 3 receptors, activates an inhibitory cyclic AMP cascade and suppresses norepinephrine-induced melatonin biosynthesis. The nicotinic response is fully developed in the third postnatal week. Prior to this timepoint, rat pinealocytes possess functional muscarinic receptors whose activation causes a rise in the intracellular calcium ion concentration through a calcium release from thapsigargin-sensitive intracellular calcium stores and an opening of store-operated calcium channels. This cascade may influence tissue differentiation and maturation of the melatonin pathway. The demonstration of functional cholinoreceptors and the ontogenetic switch from muscarinic to nicotinic signalling in rat pinealocytes supports the concept that pineal functions in mammals are influenced by neuronal inputs other than the sympathetic innervation which serves as the major regulatory system. $\subset$ Inra/Elsevier, Paris
\end{abstract}

pinealocyte (rat) / nicotinic acetylcholine receptor / muscarinic acetylcholine receptor / norepinephrine / glutamate

Résumé - Des cascades de signaux de transduction cholinergique dans les pinéalocytes du rat : aspects fonctionnel et ontogénétique. Dans les pinéalocytes du rat adulte, l'acétylcholine active des récepteurs nicotiniques dont la stimulation induit une dépolarisation cellulaire, l'ouverture des canaux de cations voltage-dépendant du type L et l'augmentation subséquent de la concentration d'ions calcium intracellulaires. Ces événements induisent la libération du glutamate qui, par son action sur des récepteurs métabotropiques de type glutamate 3 , active une cascade d'inhibition de l'AMP cyclique et réprime la biosynthèse de la mélatonine induite par la norépinéphrine. La réponse nicotinique est entièrement développée au cours de la troisième semaine postnatale. Avant ce moment, les pinéalocytes du rat possèdent des récepteurs fonctionnels muscariniques dont l'activation induit une hausse de la concentration intracellulaire d'ions calcium via la libération du calcium des réserves intracellulaires sensibles à la thapsigargine et l'ouverture des canaux de calcium actionnée par des

\footnotetext{
* Correspondence and reprints

E-mail: Korf@em.uni-frankfurt.de
} 
réserves. Cette cascade peut influencer la différentiation des tissus et la maturation des voies de synthèse de la mélatonine. La démonstration de l'existence de cholinorécepteurs fonctionnels et le changement ontogénétique des signaux muscariniques en signaux nicotiniques dans les pinéalocytes du rat soutiennent l'idée générale que les fonctions pinéales des mammifères sont influencées par des afférences différentes de l'innervation sympathique qui est le système principal de régulation. (C) Inra/ Elsevier, Paris

pinéalocyte de rat / récepteur d'acétylcholine nicotinique / récepteur de l'acétylcholine muscarinique / norépinéphrine / glutamate

\section{INTRODUCTION}

The mammalian pineal organ is an important component of the photoneuroendocrine system which rhythmically synthesizes and secretes melatonin during the night in response to photoperiodic stimuli and signals from the circadian clock in the hypothalamic suprachiasmatic nucleus. The melatonin rhythm generation depends on the sympathetic innervation of the pineal gland [12] which rhythmically releases norepinephrine (NE) at the onset of darkness [6]. By stimulating $\alpha_{1}$ - and $\beta_{1}$-adrenergic receptors, NE causes increases in the intracellular concentrations of calcium ions and cyclic AMP and shapes the melatonin rhythm by regulating the arylalkylamine$N$-acetyltransferase (AANAT), the key enzyme of the melatonin biosynthesis [14], at transcriptional and post-transcriptional levels. The transcriptional regulation of the AANAT involves activating and inhibitory transcription factors, e.g. phosphorylated CREB and ICER [17, 21, 25, 30, 32-34]; a major post-transcriptional mechanism is the cyclic AMP-dependent rapid and reversible control of selective proteasomal proteolysis [9]. All these data have corroborated the essential role of the sympathetic innervation of the pineal organ and its primary neurotransmitter, NE. In contrast, it is still unclear whether and how non-sympathetic neuronal pathways (see [15, 16, 23]) or hormones are involved in the regulation of melatonin biosynthesis and pineal function in mammals.
Out of the variety of putative neuronal and hormonal inputs to the mammalian pineal organ, the cholinergic system appears of particular interest for the following reasons. 1) Several morphological investigations point towards the existence of a parasympathetic innervation of the mammalian pineal gland (for review, see [23]) which may originate from the pterygopalatine ganglion, employ acetylcholine (ACh) as the primary neurotransmitter and antagonize the sympathetic effects. 2) A cholinergic innervation of the mammalian pineal organ has been convincingly demonstrated by immunocytochemistry using antibodies against the vesicular ACh transporter [26]. 3) Biochemical and immunocytochemical results suggest that rat pinealocytes contain $\mathrm{ACh}$ and that the ACh content increases tenfold at night [37].

Possible effects of cholinergic agonists on melatonin production and release have been repeatedly investigated (for review, see [19]), but the data are equivocal with regard to the receptor types involved, their location and the functional consequences of their activation. Transpineal in vivo microdialysis has shown that the infusion of the cholinergic agonists carbachol or oxotremorine into the pineal organ of adult rats resulted in a marked decrease in melatonin release during the dark period by inhibiting the NE release from sympathetic nerve fibres [7]. Such data suggest the presence of muscarinic acetylcholine receptors ( $\mathrm{mAChRs)}$ in a presynaptic location, i.e. on 
the sympathetic nerve endings. The existence of nicotinic $\mathrm{ACh}$ receptors ( $\mathrm{AAChRs)}$ in the rat pineal organ was inferred from immunocytochemical investigations [24] and binding studies with radiolabelled specific ligands [31] and it has been suggested that nicotine has an inhibitory effect on pineal melatonin biosynthesis.

In the last 3 years, several investigations have been performed in an attempt to clarify the cholinergic signal transduction mechanisms, using the rat pineal organ as a model. The results of these studies will be reviewed in the present contribution. Moreover, new data will be presented on the ontogenetic development of cholinergic signalling mechanisms in rat pinealocytes.

\section{CHOLINERGIC SIGNAL TRANSDUCTION IN PINEALOCYTES OF ADULT RATS}

Calcium imaging of isolated, immunocytochemically identified rat pinealocytes has shown that $\mathrm{ACh}$ increases the intracellular calcium ion concentration $\left(\left[\mathrm{Ca}^{2+}\right]_{i}\right)$ in more than $90 \%$ of the cells in a dose-dependent manner [29]. All ACh-sensitive pinealocytes also respond to NE with an increase in $\left[\mathrm{Ca}^{2+}\right]_{\mathrm{i}}$, but the two types of responses are quite different. The $\mathrm{ACh}$ induced rise in $\left[\mathrm{Ca}^{2+}\right]_{i}$ is followed by a rapid decrease to basal levels within a few minutes after the onset of the stimulus. This decrease is also seen under a constant exposure to the ligand. The response is mediated by a nicotinic receptor subtype (figure $1 A$ ) because $\mathrm{ACh}$ and nicotine elicit virtually identical effects, and both the ACh- and the nicotine-induced responses are blocked by the specific nicotinic antagonist, $d$-tubocurarine. $\mathrm{mAChRs}$ do not play a role in this calcium response because pilocarpine, acting upon all presently known muscarinic receptor subtypes, does not evoke a calcium response, and the muscarinic antagonist atropine does not block the $\mathrm{ACh}$-induced rise in $\left[\mathrm{Ca}^{2+}\right]_{\mathrm{i}}$. The response to $\mathrm{ACh}$ is totally prevented when pinealocytes were kept in calcium-free saline, indicating that the response is based upon a calcium influx.

The components involved in the nicotinic response have been identified using a combination of patch-clamp recordings and calcium imaging [20]. These investigations have shown that the average resting membrane voltage of isolated adult rat pinealocytes is $-43 \mathrm{mV}$, and that the replacement of extracellular $\mathrm{NaCl}$ by $\mathrm{KCl}$ completely depolarizes the cells. This indicates that the resting membrane voltage is dominated by a $\mathrm{K}^{+}$ conductance. Single channel recordings reveal the presence of a large conductance, $\mathrm{Ca}^{2+}$-activated, charybdotoxin-sensitive $\mathrm{K}^{+}$ channel $[4,20]$. The application of $\mathrm{ACh}$ depolarizes the pinealocytes by an average of $16 \mathrm{mV}$. The depolarizing effect of ACh is mimicked by nicotine and prevented by tubocurarine. This depolarization is largely abolished in the absence of extracellular $\mathrm{Na}^{+}$ but is not significantly affected by extracellular $\mathrm{Ca}^{2+}$ removal. Removal of extracellular $\mathrm{Na}^{+}$also causes a large reduction in the ACh-induced rise in $\left[\mathrm{Ca}^{2+}\right]_{\mathrm{i}}$. Nifedipine suppresses the $\mathrm{ACh}$-induced increase in $\left[\mathrm{Ca}^{2+}\right]_{i}$ by approximately $50 \%$. The findings indicate that $\mathrm{ACh}$ influences adult rat pinealocytes through stimulation of $n A C h R s$ which induces a depolarization mainly by a $\beta \mathrm{Na}^{+}$influx through the receptor. The depolarization then activates voltage-gate L-type calcium channels (VCCs) which are responsible for the nifedipine-sensitive portion of the $\left[\mathrm{Ca}^{2+}\right]_{\mathrm{i}}$ increase.

The fact that nicotinic receptors and VCCs are present in the vast majority of adult rat pinealocytes suggests their important role in the regulation of pineal metabolism. One idea is that ACh may act upon microvesicle-mediated glutamate release from pinealocytes which is elicited by depolarization and activation of VCCs ([39, 40]; figure 2A). Glutamate has been shown to suppress the NE-induced melatonin production in the rat pineal organ kept 
A

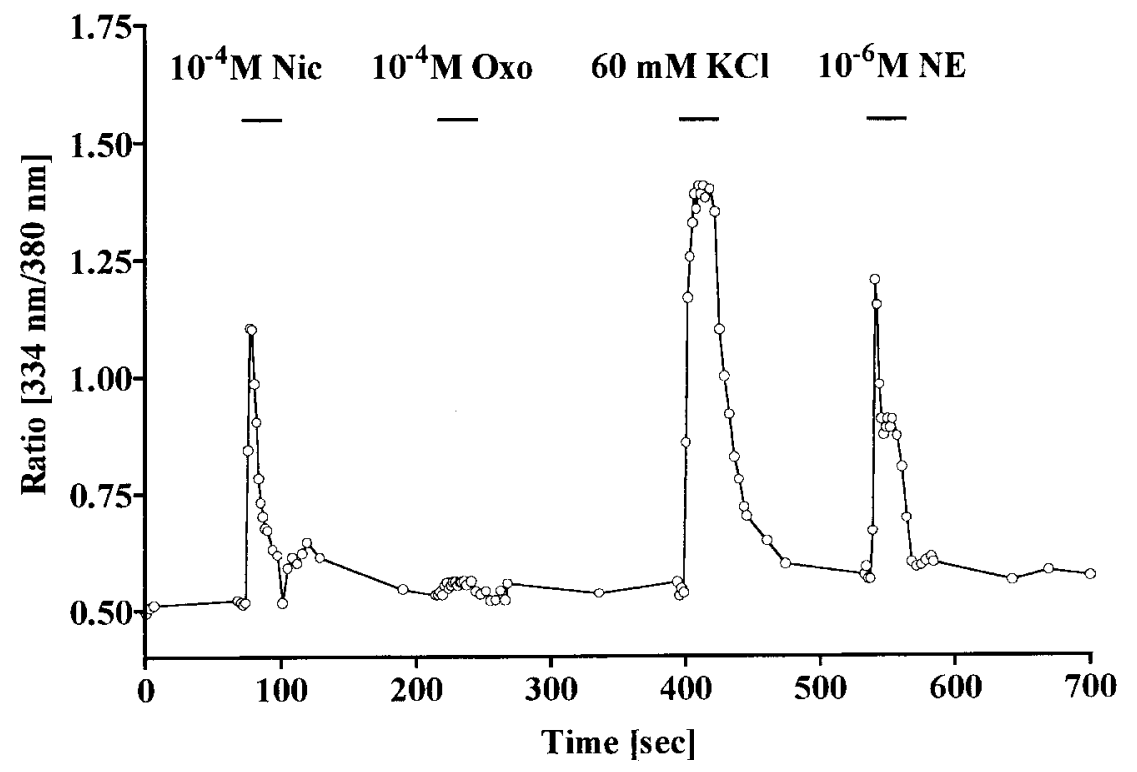

B

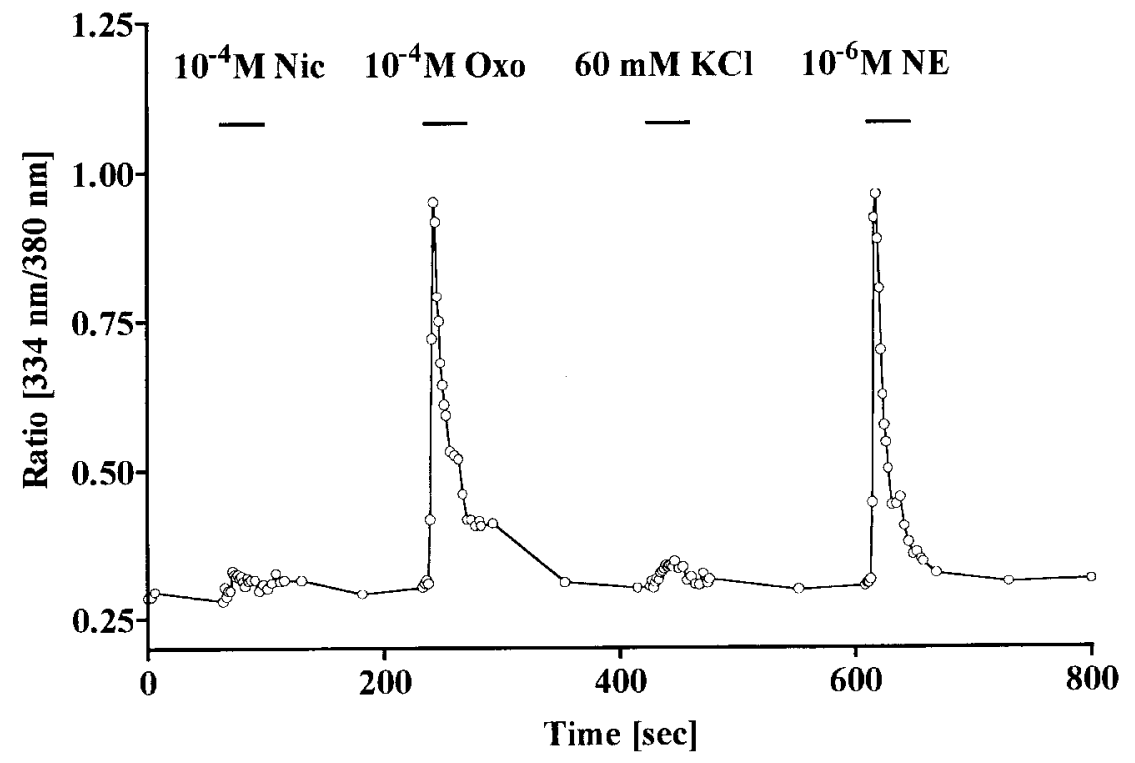

Figure 1. ACh-induced calcium responses recorded from adult and rat neonatal (P0) pinealocytes. A) In adult pinealocytes, nicotine, but not oxotremorine- $\mathrm{M}$, induces a rise in $\left[\mathrm{Ca}^{2+}\right]_{i}$. Cells showing a nicotinic response also react to $\mathrm{NE}$ and $60 \mathrm{mM} \mathrm{KCl}$ with an elevation of $\left[\mathrm{Ca}^{2+}\right]_{i}$. B) In neonatal rat pinealocytes, stimulation with oxotremorine- $\mathrm{M}\left(\mathrm{Oxo}, 10^{-4} \mathrm{M}\right)$ elicits a robust calcium signal. Pinealocytes showing a muscarinic response also react to NE with an increase in $\left[\mathrm{Ca}^{2+}\right]_{\mathrm{i}}$, whereas treatment with the nicotinic receptor agonist nicotine $\left(\mathrm{Nic} ; 10^{-4} \mathrm{M}\right)$ or $60 \mathrm{mM} \mathrm{KCl}$ does not affect $\left[\mathrm{Ca}^{2+}\right]_{i}$. 
Figure 2. Signal transduction mechanisms in pinealocytes from adult and neonatal rats. A) In pinealocytes from adult rats, acetylcholine acts upon nicotinic acetylcholine receptors (nAChR) whose stimulation causes the depolarization of the cells through a sodium ion influx, an opening of voltage-gated cation channels (VCC) and a subsequent increase in the intracellular calcium ion concentration. These events trigger a microvesicle-mediated release of glutamate that, by its action on metabotropic glutamate type 3 receptors (mGluR3), activates an inhibitory cyclic AMP cascade and suppresses norepinephrine-induced arylalkylamine- $N$-acetyltransferase (AANAT) activation and melatonin synthesis. B) In pinealocytes from neonatal rats, acetylcholine stimulates muscarinic acetylcholine receptors ( $\mathrm{mAChRs)}$ whose activation causes a rise in the intracellular calcium concentration through calcium release from thapsigargin-sensitive intracellular calcium stores and the opening of store-operated calcium channels (SOC). This cascade may influence tissue differentiation and maturation of the melatonin pathway. $\alpha_{1}$ - and $\beta_{1}$-adrenergic receptors are already functional (Schomerus, Laedtke and Korf, unpublished results) despite the fact that melatonin is not yet synthesized. HIOMT, hydroxyindole- $O$ methyltransferase; $\mathrm{G}_{\mathrm{i}}$, inhibitory GTP-binding protein; $G_{s}$, stimulatory GTP-binding protein.

in vitro [18]. This inhibitory effect of glutamate is due to the activation of metabotropic type 3 glutamate receptors initiating an inhibiting cyclic AMP cascade finally resulting in a decreased NAT activity [42]. The presumed link between the activation of nAChRs, subsequent opening of VCCs, release of glutamate and inhibition of melatonin biosynthesis and release has been experimentally proven by a recent study by Yamada and coworkers [41]. These authors showed that ACh stimulates glutamate

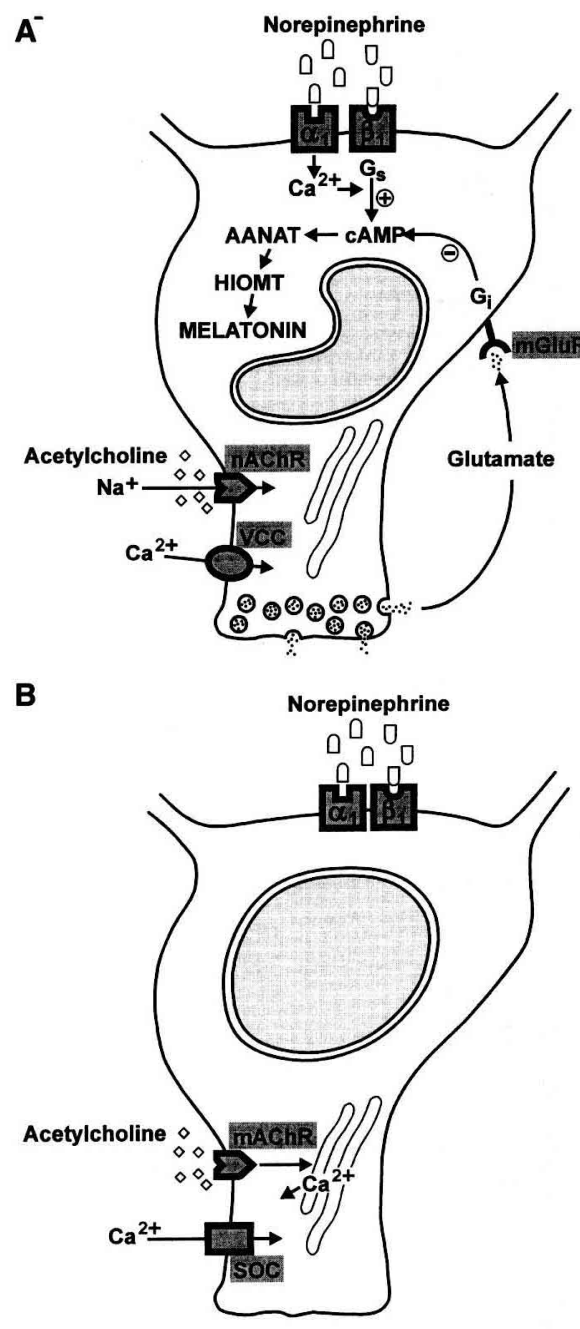

release from isolated pinealocytes of adult rats. The removal of calcium ions from the medium reduces $\mathrm{ACh}$-evoked glutamate secretion by $80 \%$. Blockers of cation channels of the L-type inhibit the ACh-evoked glutamate release, whereas channel agonists stimulate glutamate release. Glutamate secretion is triggered by nicotine, but not by muscarine. The nicotine- or ACh-evoked glutamate secretion is inhibited by $d$-tubocurarine, a competitive inhibitor of the $\mathrm{nAChR}$, whereas alpha-bungarotoxin, a selective 
inhibitor of some subtypes of $\mathrm{nAChR}$ and the muscarinic antagonists scopolamine and atropine are ineffective. These data show that an alpha-bungarotoxin-insensitive $\mathrm{nAChR}$ is responsible for glutamate secretion from adult rat pinealocytes. Both nicotine and $\mathrm{ACh}$ also strongly inhibit the NEinduced activation of AANAT and melatonin biosynthesis. This inhibition is prevented by tubocurarine and a specific antagonist of the class II metabotropic-type glutamate receptor.

The precise mechanism through which ACh inhibits NE-induced AANAT activation remains to be elucidated. As mentioned above AANAT can be regulated at the transcriptional and post-transcriptional level. The transcriptional regulation involves phosphorylation of the activating transcription factor which, however, is not affected by $\mathrm{ACh}$, nicotine or $L$-glutamate (figure $3 A$, $B)$. These results suggest that the cholinergic effects on AANAT activity are exerted at the post-transcriptional rather than the transcriptional level.

\section{ONTOGENETIC DEVELOPMENT OF CHOLINERGIC SIGNAL TRANSDUCTION IN RAT PINEALOCYTES}

To study the ontogenetic development of cholinergic signal transduction mechanisms we have investigated pinealocytes isolated from newborn, 1-, 2-, 3-, 4-, 5, 7-, 10-, 14- and 21-day-old rats. ACh at a concentration of $\geq 10^{-6} \mathrm{M}$ induces a robust biphasic rise in $\left[\mathrm{Ca}^{2+}\right]_{\mathrm{i}}$ in approximately $90 \%$ of neonatal pinealocytes (P0). A transient maximum in $\left[\mathrm{Ca}^{2+}\right]_{i}$ is followed by a sustained elevation of $\left[\mathrm{Ca}^{2+}\right]_{i}$ which finally drops to basal levels upon removal of the stimulus. Calibration of the semiquantitative ratio data revealed that, after $\mathrm{ACh}$ stimulation, $\left[\mathrm{Ca}^{2+}\right]_{\mathrm{i}}$ increases from a basal level of approximately $40 \pm 10 \mathrm{nM}$ to a maximum value of approximately $400 \pm 150 \mathrm{nM}$. The ACh-responsive cells also react to $\mathrm{NE}$ with a rise in $\left[\mathrm{Ca}^{2+}\right]_{i}$. Like $\mathrm{ACh}$, the muscarinic agonists muscarine (non-selective) and oxotremorine-M (relatively M1-selective) and the non-specific cholinergic agonist carbachol elicit a calcium signal in $90 \%$ of the cells at concentrations of $\geq 10^{-6} \mathrm{M}$. In contrast, nicotine $\left(10^{-4} \mathrm{M}\right)$ induces a weak calcium signal in less than $10 \%$ of cells only (figure $I B$ ). The muscarinic antagonists atropine (non-selective) and pirenzepine (M1-selective) totally block the AChevoked calcium signal at a concentration of $\geq 10^{-8}$ and $\geq 10^{-7} \mathrm{M}$, respectively. In contrast, the nicotinic antagonist $d$-tubocurarine $\left(10^{-4} \mathrm{M}\right)$ only partially inhibits the AChevoked rise in $\left[\mathrm{Ca}^{2+}\right]_{i}$. In the second postnatal week, the percentage of cells which clearly respond to $10^{-4} \mathrm{M}$ nicotine with a rise in $\left[\mathrm{Ca}^{2+}\right]_{\mathrm{i}}$ increases to approximately $10 \%$. These cells usually also react to $\mathrm{ACh}$ and oxotremorine- $\mathrm{M}$ at concentrations of $\geq 10^{-6} \mathrm{M}$. After the second postnatal week, the percentage of cells responding to muscarinergic stimuli decreases from $90 \%$ to approximately $50 \%$. By the end of the third postnatal week oxotremorine and muscarine at concentrations of up to $10^{-4} \mathrm{M}$ are basically without effect in most pinealocytes. In contrast, a robust calcium signal is elicited in $90 \%$ of the cells by $\mathrm{ACh}$ and nicotine when applied at $10^{-4} \mathrm{M}$. This type of pinealocyte is prevailing in adult rats (figure $1 A$ ).

These findings show that the cholinergic receptor types in rat pinealocytes undergo a striking transformation from $\mathrm{mAChRs}$ in neonatal animals to $\mathrm{nAChRs}$ in adult rats. They conform to binding studies showing that the amount of muscarinic ACh binding sites in the rat pineal organ declines in the course of ontogeny from relatively high levels early in development $[27,28]$ to low levels in adulthood $[8,19,35]$.

The developmental switch of the cholinoceptor type of rat pinealocytes is paralleled by a change in the signalling cascade distal to the receptors. As mentioned above, the nicotinic calcium response of adult rat pinealocytes involves the induc- 
A

$\begin{array}{llllll}1 & 2 & 3 & 4 & 5 & 6\end{array}$

pCREB

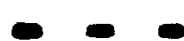

$46 \mathrm{kDa}$

$38 \mathrm{kDa}$

B

$\begin{array}{llllllllll}1 & 2 & 3 & 4 & 5 & 6 & 7 & 8 & 9 & 10\end{array}$

PCREB

$46 \mathrm{kDa}$

$38 \mathrm{kDa}$

Figure 3. Immunoblot for pCREB in pineal glands from adult rats. For immunoblotting, the pineal glands were kept in an organ culture for $24 \mathrm{~h}$ prior to the experiments, stimulated with drugs, and then homogenized in the sample buffer by sonification. Pineal protein extracts were electrophoresed and blotted onto nitrocellulose membranes that were incubated with a polyclonal antibody against pCREB. Membranes were subsequently incubated with a horseradish peroxidase-conjugated secondary antibody. Binding of the antibody was detected by chemiluminescence (UltraSignal, Pierce, Rockford, IL, USA) on autoradiographic films. Data obtained by immunoblots were analysed semiquantitatively using a computer-assisted image analysis system (KS 400, Kontron, Eching, Germany). Equal loading was ensured by incubating the membranes with a polyclonal antibody against total CREB that remained constant under the various treatment conditions. Each experiment was performed in triplicate. A) In unstimulated pineal glands, no pCREB immunoreactivity is detectable (lane 1). Treatment of glands with $\mathrm{NE}\left(10^{-7} \mathrm{M}\right)$ for $30 \mathrm{~min}$ induces pCREB immunoreactivity (lane 2). Application of ACh $\left(10^{-4} \mathrm{M}\right.$; lane 3$)$ or $L$-glutamate $\left(10^{-4} \mathrm{M}\right.$; lane 5$)$ for $30 \mathrm{~min}$ does not cause pCREB immunoreactivity. Furthermore, NEinduced pCREB immunoreactivity is not significantly affected by $\mathrm{ACh}$ or $L$-glutamate, when cultured glands are pretreated with $\mathrm{ACh}$ or $L$-glutamate and then stimulated with NE (30 min; $\left.10^{-7} \mathrm{M}\right)$ in the presence of $\mathrm{ACh}\left(10^{-4} \mathrm{M}\right.$; lane 4) and $L$-glutamate $\left(10^{-4} \mathrm{M}\right.$; lane 6$)$, respectively. B) pCREB Immunoreactivity is not detectable in unstimulated glands (lane 1) and is induced by the treatment of glands with NE for $30 \mathrm{~min}$ (lane 2), $2 \mathrm{~h}$ (lane 3), $4 \mathrm{~h}$ (lane 4), $6 \mathrm{~h}$ (lane 5) and $8 \mathrm{~h}$ (lane 6). The amount of NE-induced pCREB immunoreactivity is not affected by $L$-glutamate as shown in glands pretreated with $\operatorname{NE}\left(10^{-7} \mathrm{M}\right)$ for $30 \mathrm{~min}$ and then treated with a combination of $L$-glutamate $\left(10^{-4} \mathrm{M}\right)$ and NE $\left(10^{-7} \mathrm{M}\right)$ for $1.5 \mathrm{~h}$ (lane 7), $3.5 \mathrm{~h}$ (lane 8), $5.5 \mathrm{~h}$ (lane 9) or $7.5 \mathrm{~h}$ (lane 10). tion of a depolarizing $\mathrm{Na}^{+}$influx and the subsequent activation of $\mathrm{VCCs}$ leading to a transient rise in $\left[\mathrm{Ca}^{2+}\right]_{i}$ which is followed by a gradual drop to basal levels in the presence of the stimulus [20]. The muscarinic calcium response in neonatal pinealocytes consists of a primary phase mainly associated with the mobilization of $\mathrm{Ca}^{2+}$ from thapsigargin-sensitive intracellular stores and a secondary phase associated with $\mathrm{Ca}^{2+}$ entry into the cell (figure $2 B$ ). Interestingly, these thapsigargin-sensitive calcium stores also contribute to the calcium signal elicited by stimulation of $\alpha_{1}$-adrenergic receptors. When neonatal pinealocytes are kept in $\mathrm{Ca}^{2+}$-free saline and pretreated with $\mathrm{NE}$, they exhibit a transient increase in $\left[\mathrm{Ca}^{2+}\right]_{i}$ due to the release of calcium from intracellular compartments, but do not respond to subsequent stimulation with $\mathrm{ACh}$ in calcium-free saline. Vice versa, the depletion of these stores by ACh application prevents the response to NE. The calcium channels mediating the influx of $\mathrm{Ca}^{2+}$ in the secondary phase of the muscarinic response have not yet been identified and it remains to be established whether the calcium entry mechanism in the secondary phase of the muscarinic calcium signal is identical to that mediating the calcium influx in response to NE stimulation.

VCCs are apparently not yet developed in neonatal pinealocytes since treatment with depolarizing concentrations of $\mathrm{KCl}$ (figure $I B$ ) or the agonist Bay $\mathrm{K} 8644$ is without an effect on $\left[\mathrm{Ca}^{2+}\right]_{i}$. Accordingly, specific L-type channel antagonists (nifedipine, verapamil) do not affect the ACh-evoked, muscarinic calcium signalling.

The transformation of the cholinergic signalling system during the development of rat pinealocytes strikingly changes the spatial and temporal patterns of the $\mathrm{ACh}$ evoked calcium response. Since these patterns are considered important determinants which enhance the flexibility of $\mathrm{Ca}^{2+}$ to regulate diverse cellular processes $[2,5,10$, $22]$, the biphasic response evoked via 
mAChRs in neonatal pinealocytes is suited to promote the activation of $\mathrm{Ca}^{2+}$-sensitive events different from those activated via $\mathrm{nAChRs}$ in adult pinealocytes. A direct impact of muscarinic signalling on the regulation of melatonin production can be excluded since melatonin is not yet synthesized in the first postnatal week [13]. More likely, activation of mAChRs may play a regulatory role in the development of the pineal gland, in general, and in the maturation of the melatonin-generating system, in particular. The activation of $\mathrm{mAChRs}$ has been shown to promote cellular proliferation in neuronal and non-neuronal cells [1, 11]. In the retina, signalling via mAChRs has been proposed to be related to morphogenesis [43] and proliferation [38]. Interestingly, retinal cells also appear to express different types of cholinergic receptors during development which, it is proposed, have diverse and temporally regulated roles in their differentiation [38]. Similar differentiation processes may be controlled via mAChRs in the developing pineal organ which shares the diencephalic origin as well as photoreceptive and phototransducing properties with the retina [17]. The muscarinic response disappears concomitantly with the completion of mitosis [36]. This raises the possibility that the stimulation of $\mathrm{mAChRs}$ may also promote cell division in the pineal gland. Alternatively, muscarinic cholinergic signalling may be related to the expression of phototransduction molecules many of which are present at high levels in neonatal rat pineal organs and at low levels in adult rat pineal organs [3].

Pinealocytes lose the capacity to respond to muscarinic stimuli by the third postnatal week when the rhythmic melatonin synthesis is fully developed. The loss of the 'muscarinic phenotype' may be caused by a decrease in receptor number, decreased affinity between receptor and ligand, and/or actions distal from the mAChRs. Concomitantly, pinealocytes gain responsiveness to $\mathrm{ACh}$ via $\mathrm{nAChRs}$. The factors responsible for the differential maturation of cholinergic calcium signalling mechanisms remain unclear. The switch is obviously not caused by cell death of those pinealocytes which are endowed with a muscarinic signalling cascade since the decrease in sensitivity to $\mathrm{ACh}$ and muscarinic agonists is paralleled by an increase in responsiveness to nicotine in one and the same cell. Interestingly, the functional maturation of VCCs precedes the development of a calcium response mediated by $\mathrm{nAChRs}$. This raises the interesting hypothesis of whether the development of VCCs may induce the maturation of the 'proximal' nicotinic receptor.

\section{CONCLUSIONS}

Cholinergic signal transduction cascades operate in rat pinealocytes at all postnatal stages. In adult pinealocytes $\mathrm{ACh}$ acts upon nAChRs whose stimulation causes depolarization of the cells, opening of VCCs and a subsequent increase in the intracellular calcium ion concentration $[20,29]$. These events trigger the release of glutamate that, by its action on metabotropic glutamate type 3 receptors, activates an inhibitory cyclic AMP cascade and suppresses NE-induced NAT activation and melatonin synthesis $[41,42]$. In adult rats, mAChRs are absent from the pinealocyte membrane, but are present on sympathetic nerve fibres. Activation of these receptors blocks NE release from sympathetic nerve terminals, thus leading to a decreased melatonin output [7]. Thus, ACh appears to employ two different pathways to inhibit NE-induced melatonin synthesis and release in adult rats. The nicotinic response of rat pinealocytes is fully developed in the third postnatal week. Prior to this timepoint, rat pinealocytes express functional $\mathrm{mAChRs}$ whose activation causes a rise in the intracellular calcium ion concentration through a calcium release from thapsigargin-sensitive intracellular calcium stores and the opening of store-operated calcium channels. The functional significance of the muscarinic signal transduction cas- 
cade in pinealocytes during early postnatal development remains to be clarified. It may be assumed that this cascade influences tissue differentiation and maturation of the melatonin pathway. The demonstration of functional cholinoreceptors and the ontogenetic switch from muscarinic to nicotinic signalling in rat pinealocytes supports the concept that pineal functions in mammals are modulated by a variety of inputs that may fine-tune the signals from the major regulatory system, the sympathetic innervation.

\section{ACKNOWLEDGEMENTS}

This investigation has been supported by the Deutsche Forschungsgemeinschaft (SFB 269, Teilprojekt B2). The authors are grateful to Mrs E. Laedke for expert technical assistance and Mrs I. Szasz for excellent graphical work.

\section{REFERENCES}

[1] Ashkenazi A., Ramachandran J., Capon D.J., Acetylcholine analogue stimulates DNA synthesis in brain-derived cells via specific muscarinic receptor subtypes, Nature 340 (1989) 146-150.

[2] Berridge M.J., The AM and FM of calcium signalling, Nature 386 (1997) 759-760.

[3] Blackshaw S., Snyder S.H., Developmental expression pattern of phototransduction components in mammalian pineal implies a lightsensing function, J. Neurosci. 17 (1997) 8074-8082.

[4] Ceña V., Halperin J.I., Yeandle S., Klein D.C., Norepinephrine stimulates potassium efflux from pinealocytes: evidence for involvement of biochemical 'AND' gate operated by calcium and adenosine 3',5'-monophosphate, Endocrinology 128 (1991) 559-569.

[5] Clapham D.E., Calcium signalling, Cell 80 (1995) 259-268.

[6] Drijfhout W.J., van der Linde A.G., Kooi S.E., Grol C.J., Westerink B.H.C., Norepinephrine release in the rat pineal gland: the input from the biological clock measured by in vivo microdialysis, J. Neurochem. 66 (1996) 748-755.

[7] Drijfhout W.J., Grol C.J., Westerink B.H.C., Parasympathetic inhibition of pineal indole metabolism by prejunctional modulation of noradrenergic release, Eur. J. Pharmacol. 308 (1996) $117-124$
[8] Finocchiaro L.M.F., Scheucher A., Finkielman S. Nahmod V.E., Pirola C.J., Muscarinic effects on the hydroxy- and methoxyindole pathway in the rat pineal gland, J. Endocrinol. 123 (1989) 205-211.

[9] Gastel J.A., Roseboom P.H., Rinaldi P.A., Weller J.L., Klein D.C., Melatonin production: proteosomal proteolysis in serotonin $N$-acetyltransferase regulation, Science 279 (1998) 1358-1360.

[10] Ginty D.D., Calcium regulation of gene expression: Isn't that spatial?, Neuron 18 (1997) 183-186.

[11] Gutkind J.S., Novotny E.A., Brann M.R., Robbins K.C., Muscarinic acetylcholine receptor subtypes as agonist-dependent oncogenes, Proc. Natl. Acad. Sci. USA 88 (1991) 4703-4707.

[12] Klein D.C., Photoneural regulation of the mammalian pineal gland, in: Evered D., Clark S. (Eds), Photoperiodism, Melatonin and the Pineal Gland, Ciba Foundation Symposium 117, Pitman, London, 1985, pp. 38-56.

[13] Klein D.C., Namboodiri M.A.A., Auerbach D.A., The melatonin rhythm generating system: developmental aspects, Life Sci. 28 (1981) 1975-1986.

[14] Klein D.C., Coon S.L., Roseboom P.H., Weller J.L., Bernard M., Gastel J.A., Zatz M., Iuvone P.M., Rodriguez I.R., Bégay V., Falcón J., Cahill G.M., Cassone V.M., Baler R., The melatonin rhythm-generating enzyme: molecular regulation of serotonin $\mathrm{N}$-acetyltransferase in the pineal gland, Rec. Progr. Hormone Res. 52 (1997) 307-358.

[15] Korf H.W., Innervation of the pineal gland, in: Burnstock G., Unsicker K. (Ed.), Series on the Autonomous Nervous System, Vol. 10, Autonomic-Endocrine Interactions, Harwood, Amsterdam, 1996, pp. 129-180.

[16] Korf H.W., Møller M., The innervation of the mammalian pineal gland with special reference to central pinealopetal projections, Pineal Res. Rev. 2 (1984) 41-86.

[17] Korf H.W., Schomerus C., Stehle J.H., The pineal organ, its hormone melatonin, and the photoneuroendocrine system, Adv. Anat. Embryol. Cell Biol. 146, Springer-Verlag Berlin, Heidelberg, 1998.

[18] Kus L., Handa R.J., McNulty J.A., Glutamate inhibition of the adrenergic-stimulated production of melatonin in rat pineal gland in vitro, J. Neurochem. 62 (1994) 2241-2245.

[19] Laitinen J.T., Laitinen K.S.M., Kokkola T., Cholinergic signalling in the rat pineal gland, Cell. Mol. Neurobiol. 15 (1995) 177-192.

[20] Letz B., Schomerus C., Maronde E., Korf H.W., Korbmacher C., Stimulation of a nicotinic ACh receptor causes depolarization and activation of $\mathrm{L}$-type $\mathrm{Ca}^{2+}$ channels in rat pinealocytes, J. Physiol. 499 (1997) 329-340. 
[21] Maronde E., Schomerus C., Stehle J.H., Korf H.W., Control of CREB phosphorylation and its role for induction of melatonin synthesis in rat pinealocytes, Biol. Cell 89 (1997) 505-511.

[22] Meldolesi J., Oscillation, activation, expression, Nature 392 (1998) 863-865.

[23] Møller M., Fine structure of the pinealopetal innervation of the mammalian pineal gland, Microsc. Res. Tech. 21 (1992) 188-204.

[24] Reuss S., Schröder H., Maelicke A., Nicotinic cholinoceptors in the rat pineal gland as analyzed by western blot, light- and electron microscopy, Brain Res. 573 (1992) 114-118.

[25] Roseboom P.H., Klein, D.C., Norepinephrine stimulation of pineal cyclic AMP response element-binding protein phosphorylation: involvement of a $\beta$-adrenergic/cyclic AMP mechanism, Mol. Pharmacol. 47 (1995) 439-449.

[26] Schäfer M.K.H., Eiden L.E., Weihe E., Cholinergic neurons and terminal fields revealed by immunohistochemistry for the vesicular acetylcholine transporter. I. Central nervous system, Neuroscience 84 (1998) 331-359.

[27] Schlumpf M., Bruinink A., Lichtensteiger W. Cortés R., Palacios J.M., Pazos A., Beta adrenergic binding sites in fetal rat central nervous system and pineal gland: their relation to other receptor sites, Dev. Pharmacol. Ther. 10 (1987) $422-435$

[28] Schlumpf M., Palacios J.M., Cortés R., Lichtensteiger W., Regional development of muscarinic cholinergic binding sites in the prenatal rat brain, Neuroscience 45 (1991) 347-357.

[29] Schomerus C., Laedtke E., Korf H.W., Calcium responses of isolated, immunocytochemically identified rat pinealocytes to noradrenergic, cholinergic and vasopressinergic stimulations, Neurochem. Int. 27 (1995) 163-175.

[30] Schomerus C., Maronde E., Laedtke E. Korf H.W., Vasoactive intestinal peptide (VIP) and pituitary adenylate cyclase-activating polypeptide (PACAP) induce phosphorylation of the transcriptional factor CREB in subpopulations of rat pinealocytes: immunocytochemical and immunochemical evidence, Cell Tissue Res. 286 (1996) 305-313

[31] Stankov B., Cimino M., Marini P., Lucini V., Fraschini F., Clementi F., Identification and functional significance of nicotinic cholinergic receptors in the rat pineal gland, Neurosci. Lett. 156 (1993) 131-134

[32] Stehle J.H., Pineal gene expression: dawn in a dark matter, J. Pineal Res. 18 (1995) 179-190.
[33] Stehle J.H., Foulkes N.S., Molina C.A., Simonneaux V., Pévet P., Sassone-Corsi P., Adrenergic signals direct rhythmic expression of transcriptional repressor CREM in the pineal gland, Nature 356 (1993) 314-320.

[34] Tamotsu S., Schomerus C., Stehle J.H., Roseboom P.H., Korf H.W., Norepinephrine-induced phosphorylation of the transcription factor CREB in isolated rat pinealocytes: an immunocytochemical study, Cell Tissue Res. 282 (1995) 219-226.

[35] Taylor R.L., Albuquerque M.L.C., Burt D.R., Muscarinic receptors in pineal, Life Sci. 26 (1980) 2195-2200.

[36] Vollrath L., The pineal organ, in: Oksche A., Vollrath L. (Eds.), Handbuch der Mikroskopischen Anatomie des Menschen, vol. VI/7, Springer, Berlin, 1981

[37] Wessler I., Reinheimer T., Bittinger F., Kirkpatrick C.J., Schenda J., Vollrath L., Day-night rhythm of acetylcholine in the rat pineal gland, Neurosci. Lett. 224 (1997) 173-176.

[38] Wong R.O.L., Cholinergic regulation of $\left[\mathrm{Ca}^{2+}\right]$ during cell division and differentiation in the mammalian retina, J. Neurosci. 15 (1995) 2696-2705

[39] Yamada H., Yamamoto A., Takahashi M., Michibata H., Kumon H., Moriyama Y., The L-type $\mathrm{Ca}^{2+}$ channel is involved in microvesiclemediated glutamate exocytosis from rat pinealocytes, J. Pineal Res. 21 (1996) 165-174.

[40] Yamada H., Yamamoto A., Yodozawa S., Kozaki S., Takahashi M, Morita M., Michibata H., Furuichi T., Mikoshiba K., Moriyama Y., Microvesicle-mediated exocytosis of glutamate is a novel paracrine-like chemical transduction mechanism and inhibits melatonin secretion in rat pinealocytes, J. Pineal Res. 21 (1996) 175-191.

[41] Yamada H., Ogura A., Koizumi S., Yamaguchi A., Moriyama Y., Acetylcholine triggers $L$-glutamate exocytosis via nicotinic receptors and inhibits melatonin synthesis in rat pinealocytes, J. Neurosci. 18 (1998) 4946-4952.

[42] Yamada H., Yastushiro S., Ishio S., Hayashi M., Nishi T., Yamamoto A., Futai M., Yamaguchi A., Moriyama Y., Metabotropic glutamate receptors negatively regulate melatonin synthesis in rat pinealocytes, J. Neurosci. 18 (1998) 2056-2062.

[43] Yamashita M., Fukuda Y., Incurvation of early embryonic neural retina by acetylcholine through muscarinic receptors, Neurosci. Lett. 163 (1993) 215-218. 